\title{
DOIS DIÁRIOS, UM ENSAIO E UM ROMANCE: A PRESENÇA DE "INCIDENTES" E "NOITES DE PARIS" NA ESCRITA NARRATIVA DESEJADA POR ROLAND BARTHES
}

Priscila Pesce Lopes de Oliveira Universidade Federal do Ceará

Claudia Consuelo Amigo Pino Universidade de São Paulo/FAPESP

\section{RESUMO}

Em seus últimos anos de vida Barthes tornou público o projeto de escrever um romance provisoriamente intitulado Vita Nova, trabalho cujos traços aparecem no curso "A Preparação do Romance". Ao longo do curso ele escreveu também seu último livro publicado em vida, A Câmara Clara: nota sobre a fotografia, ao mesmo tempo em que trabalhava sobre os diários "Incidentes" e "Noites de Paris", possivelmente buscando integrá-los a Vita Nova (PINO, 2010). Esses dois diários relacionam o biográfico com a imagem de autor, a autoimagem, o afeto e a escrita, questões em pauta no romance pretendido. Seus procedimentos formais, em especial os relacionados à negociação do terreno entre narração e relato, podem mostrar-se de suma importância para uma leitura de $A$ Câmara Clara, onde essa questão concentra-se na relação do narrador com as fotografias seletas. Este artigo traça a presença de "Incidentes" e "Noites de Paris" em aspectos narrativos de A Câmara Clara que podem apontar caminhos escriturais do romance desejado por Barthes.

PALAVRAS-CHAVE: Roland Barthes, diário, Incidentes, A Câmara Clara, A Preparação do Romance 
É porque há uma angústia da banalidade que a literatura não cessa de inscrever suas informações dentro de uma área de segurança. VIGIÁ-LAS, para distanciarem-se da nomenclatura espontânea dos sentimentos.

(anotação de Ana Cristina Cesar em seu exemplar de Fragmentos de um Discurso Amoroso, de Roland Barthes; citado em CAMARGO, 2003, p. 184)

Diários de escritor são publicados (muitas vezes em vida) respondendo aos mais diversos anseios relativos a uma aproximação do autor: acesso a detalhes de sua biografia, sua rotina, seus gostos, opiniões, pensamentos, talvez seu processo criativo...

A promessa embutida em tal premissa está calcada no senso comum acerca da escrita diarística e se mostra frágil diante de um estudo especializado como o de Roland Barthes, que debruçou-se sobre o diário como prática de escrita propícia à desconfiança da noção de subjetividade. Em seus diversos diários, que têm sido objeto de publicação póstuma, bem como num artigo em que interroga a validade do diário como escrita literária (BARTHES, 2012a), o autor dedicou-se a questões formais e a uma investigação das possibilidades do gênero.

Chama a atenção nos diários barthesianos seu caráter especializado: "Incidentes" (BARTHES, 2004a) integra uma estadia no Marrocos; "Noites de Paris" (BARTHES, 2004b) acompanha as noitadas de 24 de agosto a 17 de setembro de 1979 e o Diário de Luto (BARTHES, 2011) abriga uma escrita dedicada ao processo de luto materno. Ao menos na forma publicada, todos fogem à divisa au jour le jour, atenuada por restrições de escopo. Em dois dos diários, à proposta de relato soma-se o polo da prática narrativa: ao sair de seu terreno habitual de performance autoral, a crítica e teoria literárias, o autor pode exercitar uma outra prática da linguagem ao adotar o âmbito íntimo por tema. O corpo faz-se fiel da balança nessa empreitada de dúplice investimento textual: é fiador da denotação e lastro do ethos autoral.

Neste estudo, nos aproximaremos de dois diários em que Barthes trabalhava tendo no horizonte um projeto de romance e procuraremos seguir os fios narrativos deitados pela prática diarística na escrita de seu último livro, A Câmara Clara. Por serem tais diários textos menos conhecidos, citaremos muitos trechos a fim de situar melhor o leitor. 


\section{0 terreno pantanoso da publicação póstuma}

"Incidentes" é um conjunto de textos curtos (entre 12 e 150 palavras) cuja primeira redação data provavelmente da estadia de Barthes em Marrocos, em 1968-1969. Identificamos no conjunto três grandes núcleos temáticos que frequentemente se interpenetram: usos e costumes marroquinos, o cotidiano e a sexualidade.

"Noites de Paris" foi redigido em 1979, ainda sob a sombra do luto da mãe, falecida em 1977. Aproxima-se de "Incidentes" pelo tom autobiográfico e pela abordagem direta da sexualidade: o tema são as noitadas, recheadas de flertes e michês.

O texto "Incidentes" dá título a um livro de 1987 que traz também "Noites de Paris" e dois outros textos. A publicação é de responsabilidade do editor e amigo de Barthes, François Wahl. Segundo sua apresentação do livro (WAHL, 2004, p. VIII), o texto "Incidentes" estava pronto para impressão. É uma publicação controversa: em 2009, a querela foi requentada quando Wahl, já fora da editora Seuil, opôs-se publicamente à edição do Diário de Luto, alegando que seria uma exposição indevida de intimidade e que Barthes ficaria descontente ${ }^{1}$; diversas réplicas ${ }^{2}$ revisitaram a publicação de Incidentes, segundo elas mais invasiva.

Um dos motivos da hesitação de trazer a público "Incidentes" é que, enquanto texto autobiográfico, ele participa da construção da imagem de Roland Barthes de forma bastante incisiva ${ }^{3}$ uma vez que, como afirma Dominique Maingueneau (2013), os diários podem ser considerados espaços associados da atividade autoral em regime elocutivo, isto é, que mobiliza simultaneamente diferentes instâncias autorais: pessoa civil, a imagem de autor e o elocutor construído no processo enunciativo textual.

Em A Câmara Clara, Barthes (1984, p. 146) pondera o ato de posar para retratos, o valor de verdade de fotografias "espontâneas" de pessoas públicas como ele próprio. Nesse sentido, parece-nos que "Incidentes", caso estivesse de fato pronto para publicação antes da morte de Barthes, só pôde estar cogitado para compor a imagem pública de seu autor por conta das obras publicadas na década de 1970, que trazem questões de escrita desse texto: o discurso autobiográfico como forma de pulverização do sujeito, o trabalho de linguagem que faria aceder a momentos de nãolinguagem e o fragmento como prática do descontínuo, como veremos.

Não obstante o aspecto formal, o motivo pelo qual muitos tiveram reticências para com a publicação dos diários "Incidentes" e "Noites de 
Paris" é a sexualidade tematizada sem meias-palavras. Para ilustrar, retomamos aqui a reserva do biógrafo Calvet:

(...) pode-se perguntar sobre a vontade real de Barthes de que essas linhas [Incidentes] fossem publicadas. Em 1979, na Tel Quel, ele já havia mostrado um trecho do diário (...), e acrescentou uma 'deliberação' (precisa-se ter um diário?). Mas esses textos, publicados após a morte de sua mãe, não fazem alusão alguma ao homossexualismo (sic.), e é nesse ponto, mais do que em sua ligação com os modernos (...), que a publicação de Incidentes rompe talvez um acordo tácito (...). (CALVET, 1993, p. 280-281, grifo do autor)

Diante dessas ponderações, oferecemos uma deliberação de postura e de leitura: buscar integrar "Incidentes" e "Noites de Paris", enquanto textos, à rede textual barthesiana.

\section{0 diário, o egotismo e a justeza da enunciação}

O editor afirma acerca de "Incidentes" e "Noites de Paris" que consistem num "esforço feito pela escrita para se apossar do imediato. Não são, pois, nem a pesquisa teórica nem o questionamento crítico (...) que aqui operam." (WAHL, 2004, p. VII, grifo do autor). Barthes trabalhava sobre esses dois textos durante a escrita de seu último livro, A Câmara Clara: redigia "Noites de Paris" e retomava "Incidentes", possivelmente buscando integrá-los ao projeto Vita Nova, o romance que ambicionava escrever (KNIGHT, 2016; PINO, 2010).

Os oito fólios preparatórios de Vita Nova publicados postumamente nas Obras Completas (BARTHES, 2002) mostram que o romance se ocupava das relações entre o biográfico, a imagem de autor e a autoimagem, bem como daquelas entre o afeto e a escrita. Elas estão em obra também em "Incidentes" e "Noites de Paris", cujos procedimentos formais relacionados à negociação do espaço entre narração e relato podem ser proveitosos para ler A Câmara Clara, onde essa questão concentra-se em torno da relação do narrador com as fotografias seletas.

Em 1975, no livro Roland Barthes por Roland Barthes, "Incidentes" aparece como projeto em dois fragmentos, um dos quais menciona um livro utópico de escrita ligada ao haiku que "contasse mil "incidentes", proibindo-se de jamais arrancar-lhes uma linha sequer de sentido" (BARTHES, 1977, p. 161). O projeto é assim contraposto ao movimento da escrita crítica, de falar sobre algo, que no próprio Roland Barthes já convive com oscilações rumo a um esforço para trabalhar na forma o posicionamento do autor. 
Tal ajuste fino da enunciação diz respeito a modulá-la de forma a consistir numa determinada atitude de escrita, da qual faz parte uma certa postura de enunciação. Como num regime não-ficcional o narrador tende a ser conflado ao autor, no estudo de diários pode ser tão pertinente quanto traiçoeiro perguntar-se: o que diz a narração sobre o narrador?

Em 1979, Barthes também se preocupa com isso no artigo "Deliberação":

Enfim, imagino que as minhas páginas de Diário estão colocadas sob o olhar de "para quem olho", ou sob o silêncio de "para quem falo". - Não é a situação de todo texto? - Não. O texto é anônimo, ou pelo menos produzido por uma espécie de Nome de Guerra, o do autor. O diário, de forma alguma (mesmo que o seu "eu" seja um nome falso); o Diário é um "discurso" (uma espécie de palavra "writada" segundo um código particular), não um texto. (BARTHES, 2012, p. 458)

Temos então que os diários barthesianos trabalham também em tensão com a dispersão identitária característica do Texto ${ }^{4}$. Havendo uma considerável intersecção entre narrador e elocutor, o investimento formal passa a ser também tática de composição do ethos autoral. Sobre este ponto vejamos, para fins de contraste, três trechos de diários: o primeiro é do Diário de Luto, o segundo, de "Noites de Paris", e o terceiro, de "Incidentes":

12 de fevereiro de 1978

Neve, muita neve sobre Paris; é estranho.

Digo a mim mesmo e isso me dói: ela não estará mais aqui para vê-lo, para que eu conte a ela. (BARTHES, 2011, p. 90)

(...) caminhei de volta, era tedioso, nenhuma vitrine para olhar, e sentei-me um minuto num dos bancos da pracinha; algumas crianças estavam ali jogando bola e gritando; outras brincavam de se atirar com força e cair sobre os enormes fardos de papel que o vento começava a fazer voar e a dispersar. Disse com meus botões: como isto parece cinema! Eu precisava registrar isso para inserir num filme; divaguei um pouco: imaginando uma técnica que me permitisse filmar imediatamente a cena (...). (BARTHES, 2004b, p. 63)

Pela janela do hotel, no passeio um pouco deserto (é domingo de manhã, ainda cedo: ao longe, garotos caminham pela praia para jogar fu- 
tebol), vejo um carneiro e um cachorrinho, da cauda levantada; o carneiro acompanha o cachorro passo a passo; finalmente, tenta montar nele. (BARTHES, 2004a, p. 22)

A matéria comum são cenas presenciadas na rua. $\mathrm{O}$ tratamento difere bastante: no Diário de Luto a notação do externo é gatilho do interno que, no livro, é o espaço dedicado ao que toca a falta da mãe. Em "Noites", a narração é mais detalhada: há contextualização do momento, alternância e ligação entre o monólogo interior e os estímulos externos, descrições mais elaboradas e mesmo explicações: em "tedioso, nenhuma vitrine para olhar", o narrador esclarece e defende a escolha do adjetivo, isto é, justifica seus humores, movimento prevalente na primeira parte de $A$ Câmara Clara e descartado na segunda. Já "Incidentes" é quase cinematográfico: podemos imaginá-lo como um roteiro: a câmera em travelling mostraria a janela do hotel, o céu da manhã, os garotos; depois de situar o expectador, um zoom ajustaria o enquadramento para o carneiro e o cachorrinho, a ação propriamente dita. O narrador está presente gramaticalmente ("vejo") e como ponto focal, mas não descreve sua relação afetiva com a cena - apesar de não prescindir dela: podemos depreender que o afetivo em "Incidentes", em espécie de prefiguração do punctum que seria uma das balizas analíticas de Câmara, é aquilo que toca o narrador o suficiente para que anote a cena:

$\mathrm{Na}$ estrada de Marrakech, em Beni-Mellal: um adolescente pobre, Abdelkhaim, que não fala francês, carrega um cesto rústico, redondo. Dou carona para ele por algumas centenas de metros. Mal subiu no carro, tira do cesto uma chaleira e me oferece um copo de chá quente (quente, como?); depois desce, desaparece pelo lado da estrada. (BARTHES, 2004a, p. 42)

Esse (a)notável é oferecido ao leitor. O narrador aponta seus achados, caracterizando-se justamente por esse olhar seletor. Quando o incidente é da ordem do pitoresco, parece convidar o leitor a juntar-se ao narrador para pequenos deleites e estupefações diante do comportamento exótico dos marroquinos: "Acima da porta, no cimento, o pedreiro Ahmed Midace gravou estas palavras em desajeitadas letras garrafais: COZINHA À FORÇA. O pai não queria essa cozinha acrescentada, a mãe a queria." (BARTHES, 2004a, p. 49). Incidentes singelos pintam o narrador com tons líricos, uma sensibilidade capaz de discernir o poético nas coisas simples: "Souk de Marrakech: rosas campestres em montes de menta." 
(idem, p. 41). Incidentes picantes caracterizam o narrador como sincero e aberto, pois estaria disposto a falar de assuntos privados (o sexo) e tabu (relações homossexuais):

Driss A. não sabe que a porra se chama porra; ele a chama de merda: "Atenção, a merda vai sair": nada mais traumatizante.

Outro Slaui (Mohamed Ginástica) diz seca e exatamente: ejacular: "Atenção, vou ejacular." (idem, p. 27)

O humor, a sensibilidade e a sinceridade estão em jogo no tom desse texto (esta última também como movimentação dentro do quadro genérico do diário íntimo) e delineiam ali um ethos narrativo que propõe parâmetros de leitura: no mesmo gesto de mostrar-se, o narrador convida para um sorriso cúmplice, solicita a simpatia do leitor.

Em um contexto racional e técnico de relação com o discurso, o aceite das proposições do locutor por parte do interlocutor pode ser caracterizado como adesão; por sua vez, a simpatia tem um componente afetivo, que destaca a dimensão de contato interpessoal do texto (a função fática discriminada por Jakobson em seu celebérrimo "Linguística e Poética"). Por conta de sua participação no nome de autor, o afeto destinado ao narrador de "Incidentes" pode ser redirecionado àquele que assina Roland Barthes.

A questão não passa pela simples identificação do leitor com o narrador nem por uma intersecção total entre este e o escritor; antes, diz respeito ao levantado por Philippe Roger (1986, p. 171), para quem no Roland Barthes por Roland Barthes vigora uma concepção de sujeito como efeito de linguagem: "Escrevo um texto e o chamo de R.B." (BARTHES, 1977, p. 64). A constituição discursiva desse sujeito é reforçada por Rabaté, que observa, também a respeito do Roland Barthes, que ela não dispensa um corpo:

A prática do fragmento é aqui de ordem ética: a afirmação de uma verdade (do sujeito) permanece provisória (...). Se é preciso um EU, é porque não se poderia dispensar um corpo (...), porque somente um corpo pode ser emocionado, tocado. Mas esse EU não adquire espessura (...) ele serve mais (como o EU do comentário em relação a um texto) como mediador estrutural dos efeitos de linguagem ou de emoção sobre ele. ${ }^{5}$ (RABATÉ, 2002, p. 200, grifo do autor, tradução nossa)

Esse corpo discursivo que, oscilante, afirma no fragmento uma pulverização constitutiva do sujeito constrói-se em jogo com os parâmetros 
de gênero textual. Em "Incidentes", estes são o diário íntimo e o haiku, em torno dos quais Barthes organiza discursivamente seu narrador. $\mathrm{O}$ primeiro evoca fortemente o escritor como componente de leitura, como pondera Barthes no já citado "Deliberação":

(...) constituir o autor em objeto de desejo: de um escritor que me interessa, posso gostar de conhecer a intimidade, a distribuição cotidiana do seu tempo, dos seus gostos, dos seus humores, dos seus escrúpulos; posso chegar até a preferir a sua pessoa à sua obra, lançar-me avidamente sobre o seu Diário e desleixar os seus livros. Posso então, fazendo-me o autor do prazer que outros souberam me dar, tentar por minha vez seduzir, por esse torniquete que faz passar do escritor à pessoa, e vice-versa (...). (BARTHES, 2012, p. 447)

Contudo, em "Incidentes" o narrador não convoca a referência extradiscursiva: não se nomeia, tampouco apresenta um centro organizador na letra do texto: de um total de 124 incidentes, 13 trazem o pronome "eu" e outros 27 , pronomes pessoais ou verbos conjugados na primeira pessoa. A narração não informa datas, não concatena episódios, não descreve o narrador (idade, nacionalidade, profissão), não explica o motivo de sua estadia no Marrocos, quanto tempo ficou, por quais locais passou etc. Temos os detalhes da experiência sem o contorno que direcione explicitamente sua significação dentro de um quadro da personalidade do narrador, distanciando essa escrita de uma manifestação de um indiviso indivíduo apriorístico. Em termos barthesianos, a questão se coloca da seguinte forma: "Como redigir um Diário sem egotismo?" (BARTHES, 2012, p. 459).

Em "Incidentes", uma tradução da experiência narrada em caracterização do narrador ou uma composição deste precisa ser empreendida (desejada) pelo leitor: a exposição não é negada mas, não sendo tampouco dada, propõe-se como atividade a dois na leitura - como a fotografia erótica descrita em A Câmara Clara, que "leva o expectador para fora de seu enquadramento, e é nisso que essa foto me anima e eu a animo" (BARTHES, 1984, p. 89).

Por fim, "Incidentes" opera uma concepção dispersa de sujeito, semelhante à proposta por Barthes em suas leituras do haiku. A reflexão barthesiana sobre o haiku é bastante vasta, proporcionando pesquisas à parte ${ }^{6}$. Nas aulas do curso $A$ Preparação do Romance dedicadas a esse gênero identificamos algumas semelhanças com os "Incidentes": microextensão, situação de viagem, tempo descontínuo, presença de referentes e situações concretas, recusa de asserção. 
O ponto acerca do haiku pertinente à discussão da caracterização do narrador de "Incidentes" é o conceito de individuação, que vem sanar a seguinte inquietação: como se faz a escrita do corpo e das sensações sem um sujeito, concepção clássica que tudo organiza? Conforme a aula de Preparação (BARTHES, 2003, p. 106): o haiku seria a conjunção de uma forma e de uma verdade do instante (um corpo, uma sensação, em um instante determinados). É um particular despersonalizado, que implica uma presença corporal e não se esgota na significação ativa por parte de seu autor, comportando um apelo do obtuso referente. Vemos algo nesse sentido em certos incidentes:

Num restaurante de Rabat, quatro homens do campo - em meio aos molhos, às saladas, às carnes e aos ternos-casacos - bebem leite bem doce e comem lentamente pão, mordendo um filão grande. (BARTHES, 2004a, p. 24)

Medina: seis horas da tarde, na rua pontilhada de pequenos vendedores isolados, um homem triste oferece um único facão, à beira da calçada. (idem, p. 37)

Guardada a heterogeneidade interna ao conjunto, podemos dizer que "Incidentes" aproveita procedimentos do haiku barthesiano, como a individuação, para subverter o diário: investe em uma personalização seletiva, tensionada.

Outro aspecto que tomamos como indicativo de um sistemático apagamento da subjetividade do locutor são o que chamaremos de parênteses reflexivos.

Uma menina me pede esmola: "Meu pai morreu. É para comprar um caderno etc." (O desagradável da mendicância é a viscosidade dos estereótipos.) (BARTHES, 2004a, p. 43)

Banco: um mendigo cego entra cambaleando, apalpa com sua bengala tateante as portas, os balcões, os guichês, toca nas paredes do dinheiro. Um cliente dá-lhe uma moeda. O caixa: "Não faça isso: não se deve deixá-lo mal acostumado." (Como uma mosca que só atrapalha ao cabo de algum tempo.) (idem, p. 27-28)

Uma menina é corrigida em público pela mãe camponesa. A menina solta gritos. A mãe permanece calma, obstinada; ela agarrou os cabelos da filha como uma peça de roupa e bate nela com golpes regulares na cabeça. Imediatamente, fecha-se a roda. Julgamento do massagista: a 
mãe está certa. - Mas por quê? - A menina é uma puta (na verdade, ele nada sabe sobre ela). (idem, p. 16)

Esses parênteses relegam a atribuição explícita de sentido a uma outra camada do texto, demarcada graficamente por meio de uma convenção tipográfica para circunscrever o que não é essencial. Convivem em "Incidentes" duas escritas: a que é feita em profundidade (que descobre o funcionamento) e aquela que desliza - toca levemente o referente, a sensação, sem perfurá-los, a qual vemos como aceno ao haiku.

Levantamos essa dinâmica da imbricação de comentário na descrição em vista do movimento de A Câmara Clara: na parte I do livro, a fotografia bem-sucedida é aquela que se anula enquanto mediação, tornando o mais direto possível o contato com o referente, e o punctum consiste no detalhe, num furo que esvazia a declaração do produtor (no caso, o fotógrafo) em proveito da deriva do observador (no caso, o narrador):

Um detalhe conquista toda minha leitura; trata-se de uma mutação viva de meu interesse, de uma fulguração. (...) é o indesenvolvível, uma essência (de ferida), o que não pode transformar-se, mas apenas repetir-se (...). Isso aproxima a Fotografia (certas fotografias) do Haiku. Pois a notação de um haiku também é indesenvolvível: tudo está dado, sem provocar a vontade ou mesmo a possibilidade de uma expansão retórica. (BARTHES, 1984, p. 78)

No cotejo de Câmara e "Incidentes", é possível pensar nos parênteses deste como um recurso purgante da narração a silenciar o comentário, em encenação de uma passagem direta do prazer/interesse do corpo que anota a uma fulguração no corpo que lê; Fontanari também localiza esse apagamento seletivo do narrador como um dos pontos de interesse barthesiano no haiku, que seria "uma forma de enunciação que se inscreve sob o movimento de elipse, máxima condensação, contração de uma cena de tal maneira a torná-la justa sobre a medida de uma pequena cena que não tem nada a ver com a narração" (FONTANARI, no prelo, p. 194).

"Incidentes" e o Roland Barthes por Roland Barthes afirmam inequivocamente, contra os acordos subjacentes aos gêneros textuais em relação aos quais se propõem (implicação de uma figuração denotativa de uma entidade extratextual), que o corpo ali presente é o corpo público da escrita. Se há naquelas tramas algo além da escrita, não é um escritor constituído previamente à enunciação; se um "eu" está presente, não é como ponto de apoio estável, antes como algo que persiste após todos os esforços corrosivos do Texto, em uma sobrevida desfigurada e, contudo, 
pulsante. Assim, “Incidentes" vem-nos à mente com as seguintes linhas, oferecidas por Barthes uma década depois como fechamento de sua deliberação acerca da escrita diarística:

Sim, é isso aí o Diário ideal: a uma só vez um ritmo (queda e subida, elasticidade) e um engodo (não consigo atingir a minha imagem); um escrito, em suma, que diz a verdade do engodo e garante essa verdade pela mais formal das opções, o ritmo. Com o que teríamos sem dúvida de concluir que posso salvar o Diário com a condição única de trabalhá-lo até à morte, até ao ponto da fadiga extrema, como um Texto mais ou menos impossível: trabalho a cujo termo é bem possível que o Diário assim redigido não se pareça em nada com um Diário. (BARTHES, 2012, p. 462, grifos do autor)

Em sua aproximação de "Deliberação", intitulada "Le journal et l'antijournal" [O diário e o antidiário], Gérard Genette (1981, p. 321) nota que o artigo barthesiano, ao circundar a questão de publicar ou não um diário, traz já trechos de um texto do gênero, respondendo parcialmente ao questionamento fundador que, a partir dessa aposta, poderia ser reformulado como: "Posso continuar a publicar esse tipo de textos?". Acrescentaríamos: meus diários "passam" enquanto exemplos contrabandeados num invólucro crítico, mas será que se sustentam por si mesmos, enquanto obra estética?

\section{0 retorno amigável $\mathrm{do} \mathrm{eu}$}

O trecho selecionado para contracapa de Incidentes, ao qual voltaremos, afirma que nos textos ali recolhidos Barthes está em situação de produção (escritural). A figuração da escrita em "Incidentes" pode, se lida em rede com um fragmento de Roland Barthes por Roland Barthes em que o autor descreve ter avistado André Gide (BARTHES, 1977, p. 85), ser alinhavada a uma postura de escritor. No seguinte incidente a implicação é que, como Gide, o narrador barthesiano andava com uma caderneta para tomar notas:

Um certo Jean, jovem professor - de quê? -, se debruça sobre meu livro: "Nunca consegui engolir esse cara (Proust); mas sinto que isso vai chegar." Seu amigo, Pierre, espantadíssimo, desdenhoso e seco (indiferente à resposta): "O senhor está fazendo anotações?" (BARTHES, 2004, p. 45)

Essa passagem de Barthes a uma posição de narrador envolve negociar o espaço entre relato e narração. Uma liberdade narrativa com 
acesso às experiências biográficas foi conquistada sucessivamente pelo esvaziamento / injeção seletiva do eu em livros como Roland Barthes por Roland Barthes e Fragmentos do Discurso Amoroso, em que o eu extratextual está presente com um fino trabalho de problematização ${ }^{7}$. Após essa destilação, o "eu" pode ressurgir, liberado da exibição de uma verdade. É nesse retorno amigável do eu que encontramos similaridades entre "Noites de Paris" e A Câmara Clara, as quais abordaremos aqui em dois quesitos: o retorno dos fios narrativos e a inclusão explícita daquele que fala na cena discursiva.

\subsection{Fios narrativos e o labirinto dos fragmentos}

Em "Incidentes" vigora a pulverização temporal pela ausência de fios narrativos; salvo um "primo do rei" e o menino Amidu, as personagens não recorrem. Já em "Noites de Paris", datado e disposto segundo uma progressão temporal, temos um circuito habitual de cafés e restaurantes, acompanhamos o declínio do relacionamento do narrador com um namorado, avança a leitura das Memórias de além-túmulo:

24 de agosto de 1979

(...) na cama, pois olhei as primeiras páginas de um texto, $M / S$, que acaba de ser publicado pela editora Seuil (F.W. me falara dele), perguntando-me o que poderia dizer a respeito e não encontrando - embora estivesse bem escrito e fosse simpático - senão: "sim, sim", depois continuei, apaixonadamente, a história de Napoleão nas Memórias de além-túmulo. (BARTHES, 2004b, p. 65)

25 de agosto de 1979

(...) Na cama, à noite, (...), continuei um pouco o último Navarre (melhor que os outros) e $M / S$ ("sim, sim"); mas são como lições de casa e, uma vez paga minha dívida (em prestações), fecho e volto com alívio para as Memórias de além-túmulo, o verdadeiro livro. (idem, p. 68-69)

27 de agosto de 1979

(...) Na cama, sem me forçar a ler os fardos modernos, retomo imediatamente Chateaubriand: página admirável sobre a exumação de Napoleão em Santa Helena. (idem, p. 77) 
A retomada dos fios narrativos está presente também em A Câmara Clara que, diferentemente de seus predecessores imediatos, Roland Barthes por Roland Barthes (1975) e Fragmentos de um Discurso Amoroso (1977), não propõe expressamente uma leitura não-linear. Há capítulos numerados sequencialmente e diversas referências aos trechos precedentes.

Se nos projetos barthesianos da década de 1970 (O Império dos Signos, O Prazer do Texto, Roland Barthes por Roland Barthes, Fragmentos de um Discurso Amoroso) a forma fragmentária era preferida por uma série de implicações estéticas, à época do projeto de romance Vita Nova ela traz também uma certa insuficiência (BARTHES, 2003, p. 47). Sucintamente, se por um lado o fragmento corporifica a liberdade da ausência de conclusão e o aplainamento da hierarquia entre os componentes, por outro, ele não se encaixa na prática desejada, a do romance nos moldes de Em Busca do Tempo Perdido e Guerra e Paz.

A escrita que superaria essa dicotomia está no plano da virtualidade, uma vez que Barthes faleceu antes de publicar seu romance ou anunciar publicamente que desistira do projeto. Hipóteses diversas e interessantes vêm sendo tecidas pela fortuna crítica. De nossa parte propomos que, assim como fez com o "eu", Barthes se dedicasse a depurar a escrita fragmentária para chegar ao "bom" fragmento, de modo a contornar suas características indesejáveis na empreitada romanesca. Na conferência "Durante muito tempo fui dormir cedo", ele propõe, acerca do início do romance proustiano: “(...) abalada a cronologia, fragmentos, intelectuais ou narrativos, vão formar uma seqüência que se subtrai à lei ancestral da Narrativa ou do Raciocínio, e essa seqüência produzirá, sem forçar, a terceira forma, nem Ensaio, nem Romance" (BARTHES, 2012b, p. 353, grifo do autor). É possível pensar em uma terceira forma que deslocasse a escrita fragmentária sem a preterir. Aventamos que essa busca esteja presente também em A Câmara Clara, que avançaria no sentido de superar as limitações do fragmento ao desenvolver uma espécie de equilíbrio tênue entre este e a escrita de fôlego.

Apesar de não prescindir de aspectos fragmentários, como a estrutura em pequenas partes, nem dos cortes, pausas e saltos como recursos discursivos, Câmara é um texto que não suporta permutação interna. Os capítulos são numerados e de fato traçam uma trilha:

Na época (no início deste livro: já está longe) em que me interrogava 
sobre minha ligação com certas fotos, eu julgava poder distinguir um campo de interesse cultural (o studium) e essa zebrura inesperada que às vezes vinha atravessar esse campo e que eu chamava de punctum. Sei agora que existe um outro punctum (um outro "estigma") que não o "detalhe". (BARTHES, 1984, p. 141, negrito nosso)

Assim, Câmara convida a múltiplas dinâmicas de leitura. Pensando na agonia discutida na Preparação do Romance (BARTHES, 2003, p. 137) acerca da passagem do fragmento à escrita de fôlego, parece-nos que parte da organização de Câmara consiste em fazer de cada pequeno fim um começo, não de outra unidade textual distinta da anterior e a ela equivalente, mas de uma sobrevida.

A sobrevida é um dos cernes de Câmara: o amor pela mãe sobrevive ao falecimento dela. Esfacelou-se a identificação entre permanência e identidade: contrariamente ao navio Argos, evocado no Roland Barthes como metáfora da identidade de função, não de essência (BARTHES, 1977, p. 52-53), o amor pela mãe extravasa sua aplicabilidade (a duração de seu objeto). Câmara comporta o fluxo temporal no luto, no reconhecimento da irreversibilidade da perda, mas aponta o extra-temporal como vertigem: a mãe criança, como veremos a seguir.

A nova escrita (romanesca) desejada por Barthes é instauradora, foge do falar sobre, procura fazer existir: como lemos no trecho de "Durante muito tempo, fui dormir cedo" escolhido para contracapa da edição francesa de Incidentes:

Coloco-me realmente na posição de quem $f a z$ alguma coisa, e não mais de quem fala sobre alguma coisa: não estudo um produto, endosso uma produção; elimino o discurso sobre o discurso; o mundo já não vem a mim sob a forma de um objeto, mas sob a de uma escritura, quer dizer, de uma prática (...). (BARTHES, 2012b, p. 363, grifos do autor)

O narrador de Câmara está às voltas com escrever um amor que perdura, diferente dos outros que participaram da escrita de Barthes: em "Incidentes", Fragmentos de um Discurso Amoroso e "Noites de Paris" há sempre na figuração ou discussão dos amores a sombra do fim recente ou iminente. Em termos de estrutura textual, fragmentária nesses três exemplos, a constante mudança é eufórica em "Incidentes" e no Roland Barthes, relacionada à vontade de não ser congelado numa imagem, e tem tons disfóricos em Fragmentos, em "Noites de Paris" e na Preparação do Romance, onde o fragmento é sentido como uma impotência. 
É na escrita que se propõe como monumento a um amor duradouro que vemos uma valoração positiva da permanência, na medida em que esta passa a ser compatível com a variação. Ao identificar em sua mãe o Soberano Bem e reconhecê-lo em uma fotografia da mãe criança (BARTHES, 1984, p. 101-104), Barthes entrevê a consistência como uma escolha. Se antes a prática do fragmento se fazia enquanto posição teórico-crítica (não escamotear a incontornável complexidade da enunciação; explicitar o engodo que seria um sujeito constante e pré-existente ao discurso), nesta nova volta da espiral, a consistência passa a ser apreendida fora de uma dicotomia e passa a ser um exercício expressivo. A continuidade se faz assim possível, se não como afirmação, ao menos como oscilação, na estrutura d'A Câmara Clara.

A dinâmica de neutralização de oposições vigora também no próximo quesito de reabilitação do "eu" na escrita barthesiana.

\subsection{Valendo mais do que um efeito de linguagem}

Temos procurado mostrar no trabalho de escrita de Barthes uma dinâmica de perturbação dos gêneros com os quais dialogam seus textos. Diferentemente da estratégia de contraproposta, que em um ataque contra a validade do sistema vigente busca suplantá-lo por um outro conjunto (implicitamente melhor) de regras e valores, a perturbação aponta para a insuficiência do sistema diante do irredutível: dos seres, dos discursos, das obras, das possibilidades.

Barthes distende e retorce a escrita íntima em "Incidentes" e a autoescrita no Roland Barthes por Roland Barthes, apontando o tempo todo para a irredutibilidade da escrita a uma expressão/referência implícita no senso comum desses quadros genéricos. Quando a escrita do eu esburaca-o a ponto de torná-lo uma aventura conjunta de autor e leitor, o arraigamento da escrita em uma biografia pode dar-se de modo elaborado, como projeto.

Lemos esse projeto de inclusão de um certo "eu" na escrita como recorrência de uma reivindicação: "valho mais do que aquilo que escrevo” (BARTHES, 1977, p. 148; 2004b, p. 82; 2012a, p. 447). Os diários apresentam-se em nosso exame como um espaço de ensaio de uma escrita muito específica que incorpora irrecuperavelmente, pela figuração e recursos narrativos, traços do corpo do escritor na imagem de autor.

No caso de escritos íntimos de pessoas públicas, como era o próprio Barthes, o interesse prévio está fincado no "corpo público" da imagem de autor. Ao preocupar-se (por escrito) em valer mais do que aquilo 
que escreve, Barthes assinala que há algo que, se não antecede a escrita, excede-a, no sentido de não estar completamente limitado a ela. Contudo, a criação de valor desse excedente extratextual só pode ocorrer mediante sua inclusão no espaço valorativo do texto. Trata-se de um infiltrar de Roland na imagem autoral de Barthes, viabilizando um fluxo clandestino do afeto dos leitores para o corpo do escritor. Vejamos alguns procedimentos utilizados nesse sentido em dois textos nos quais identificamos retornos amigáveis do eu: "Noites de Paris" e A Câmara Clara.

Em artigo que aborda a deliberação barthesiana acerca do interesse da escrita diarística enquanto prática literária válida especificamente para Barthes em relação com o sistema inaciano de escolha cartografado pelo autor no livro Sade, Fourier, Loyola e com a exploração do dilema performada no curso A Preparação do Romance, Diana Knight (2016) discute o parcialmente inédito Diário de Urt ${ }^{8}$ juntamente com o Diário de Luto e "Noites de Paris". Os três diários são ali tratados como exercícios de escritura claramente relacionados ao projeto Vita Nova e, o que é mais interessante, escritas às quais Barthes retornava, relia, reavaliava, como se lê por vezes nos diários de Luto e de Urt:

Todavia, relendo este Diário uma última vez, o desejo de continuar retorna.

\section{8 de agosto (de volta a Paris)}

Abandonei o diário durante toda a última parte de minha estadia em Urt. Perda de investimento na escrita, falta de ideias. (BARTHES apud KNIGHT, 2016, p. 232)

Knight (2016, p. 233) aponta que muitas das metarreflexões acerca da continuidade e validade do Diário de Urt foram retrabalhadas para integrar a introdução e conclusão de "Deliberação". Por sua vez, os diários que enfocamos no presente estudo não apresentam, em sua forma publicada, esse tipo de reflexão explícita; o narrador é por vezes figurado a escrever, mas os textos não discutem a prática escritural. Contudo, considerando o momento em que Barthes trabalha sobre eles, quer seja na redação inicial ("Noites de Paris") ou como retomada de um texto engavetado porém não descartado ("Incidentes"), esses diários podem representar uma via indicada por Genette (1981) em sua aproximação de "Deliberação": em paralelo a ponderar criticamente sobre a validade de um diário seu enquanto literatura - movimento de A Preparação do Ro- 
mance e "Deliberação" -, Barthes procuraria na própria prática diarística obter, ao termo de insistente trabalho, um produto literariamente satisfatório: "Modulação absolutamente singular dessa questão característica de certa literatura moderna (Flaubert, Proust, Kafka), que [Barthes] não deixou de interrogar ansiosamente: Escrevo para saber se consigo, se devo escrever"9 (GENETTE, 1981, p. 321, tradução nossa).

É o que buscamos mapear neste texto, colocando em relevo alguns dos caminhos e descaminhos narrativos traçados pelas páginas dos diários em que Barthes não escreve sobre escritos, próprios ou de outros, ou sobre escrever, mas para escrever. Esse desejo de passagem é explicitado em marginália trazida à luz por Knight:

O manuscrito de "Deliberação" tem também algumas anotações marginais intrigantes na "Noite Vã": "Início de um Romance à moda antiga"; "Sinto aqui a inflexão que transformaria o $e u$ autobiográfico no $e u$ de um personagem romanesco.". Em resumo, parece provável que o Diário de Urt, com as "Noites de Paris" já despontando nas últimas anotações, apesar de ter sido escrito nas circunstâncias difíceis da piora acentuada de saúde da mãe, foi concebido como teste e reflexão acerca do valor da forma diário como literatura. ${ }^{10}$ (KNIGHT, 2016, p. 234, grifos do autor, tradução nossa)

"Noites de Paris" é contemporâneo ao Diário de Urt, que tem um trecho reproduzido no artigo "Deliberação", cujo último parágrafo trazemos:

Paris, 25 de abril de 1979

Noite vã. (...)

$\mathrm{Na}$ galeria do Impasse (estropiado), fiquei decepcionado: não pelas fotografias de D.B. (são janelas, cortinas azuis fotografadas em sobretons com Polaroid), mas pelo ambiente gelado do vernissage: W. não estava lá (provavelmente na América ainda), R. também não (ia me esquecendo: eles estão brigados). D.S., bela e imponente, disse-me: "É bonito, não é? - Sim, é bonito" (mas é pouco, não há o suficiente, acrescentei comigo mesmo). Tudo aquilo estava pobre. E, como ao envelhecer estou ficando cada vez com mais coragem de fazer o que me agrada, depois de dar uma volta rápida na sala (...) saí à francesa, e lancei-me numa vagabundagem pouco útil, de ônibus em ônibus e de cinema em cinema. Eu estava gelado, fiquei com medo de pegar uma bronquite (pensei nisso várias vezes). Para terminar, aqueci-me um pouco no Flore, comendo ali alguns ovos e tomando um copo de bordeaux, embora tenha sido um dia muito ruim: público insípido e 
arrogante; nenhum rosto por que interessar-se ou sobre o qual fantasiar, ou ao menos fabular. O malogro lamentável da noite levou-me a tentar aplicar finalmente a reforma de vida que tenho na cabeça há muito tempo. Disso esta primeira nota é o vestígio. (BARTHES, 2012, p. 457)

Meses mais tarde, outra noite vã dentre as "Noites de Paris":

10 de setembro de 1979

Ontem, no fim da tarde, no Flore, eu estava lendo os Pensamentos de Pascal; (...). Fora, faz um tempo tempestuoso, há gotas de chuva - e, naturalmente, táxi não. Com Saul T., esta noite nada excêntrico, terno cinza de passeio, camisa vermelha, desistimos do Bofinger e vamos ao pequeno chinês da rua de Tournon. Saul parece deprimido e a noitada se arrasta; fico entediado, interesso-me pelos nossos vizinhos: uma negra opulenta para quem o garçonzinho vietnamita joga umas cantadas, dois franceses dos quais um é bastante bonito; ele colocou ao lado dele sua carteira e, em cima, umas chaves; o outro desce duas vezes para urinar; eles falam de tênis, pronunciam bem à francesa Flushing Meadows, Wimbledon, tomam vinho rosé. Era, entretanto, o dia em que o jogo lançado em julho devia resolver-se, Saul devia dar-me uma resposta. Mas eu já não o desejava, estava cansado, até sem ânimo para terminar o jogo. Não disse nada, e ele tampouco, sem dúvida. Depois de tudo, era isso a dupla resposta. Excelente método para secar o desejo: contrato a longo termo; isso acaba caindo sozinho. Na cama, terminei o Dante de Renucci; como é ruim! Não consigo tirar nada dele. (BARTHES, 2004d, p. 102)

Os dois excertos são datados, um deles localizado também no espaço; há identificação nominal de lugares e pessoas, por vezes indicadas por iniciais. A presença de nomes próprios em "Noites de Paris" acolhe uma certa facilidade para que o público leitor identifique as pessoas tornadas personagens do diário: por exemplo, de posse das iniciais D.B. e sabendo que é um fotógrafo que expunha em abril de 1979 uma série de trabalhos explorando cortinas azuis, não é difícil supor que se trate do autor da fotografia que faz as vezes de prólogo de A Câmara Clara, Daniel Boudinet. Não é de nosso interesse empreender uma decifração; notamos apenas que ela se apresenta como uma possibilidade nada remota de leitura, em função do nome de autor. Saber que "Incidentes" é texto barthesiano não ajuda a identificar Amidu, Siri ou outros ali nomeados; em "Noites de Paris", certos personagens são pessoas públicas e o nome Roland Barthes opera como chave de identificação de tantas outras. Essa facilidade de estabelecimento 
de balizas extratextuais fortalece a potencialidade referencial da leitura, por sua vez robustecendo o vínculo entre o nome de autor e o escritor.

Nessa linha, vemos também que "Noites de Paris" se aproxima de lugares-comuns do gênero diário e não empreende algumas das deformações operadas neste por "Incidentes": as ações narradas estão centradas no narrador e há referências a atividades e acontecimentos anteriores (uma reforma de vida, uma paquera-jogo) com desdobramentos no presente da narrativa, indicando sem cessar um intercâmbio entre a escrita e algo que a transborda.

O tom das "Noites" é confidencial, para o que contribui a discussão de experiências eróticas e românticas, pois convencionalmente são temas privados, reservados a interlocutores que possam bem acolhê-los - em especial quando a maior parte das paqueras são desventuras. Essa frustração figurada favorece o tom íntimo ao entabelar uma conversa com alguém tornado próximo o suficiente para receber sem pensar mal do narrador sua decepção com o ambiente do vernissage e com o livro de Renucci, especialmente tendo em vista que o pronunciamento de um crítico traz a expectativa de uma análise corroborativa. A leitura antes de dormir, inclusive, é uma atividade figurada que sinaliza o intercâmbio entre o âmbito íntimo, "extracurricular", e a imagem de autor: as Memórias de além-túmulo são referência frequente no curso A Preparação do Roman$c e$. Temos assim que o "eu" de "Noites", como um erro de impressão, não coincide totalmente com a imagem de autor nem está dela completamente descolado; em outros termos, não está circunscrito à escrita na enunciação em curso, nem investe no completo contrário; antes, propõe o diário como zona franca de fluxo entre a prática de escrita e tudo o que (ainda?) não faz parte dela.

Para pensar melhor nessa questão voltemos, por fim, aos trechos das noites vãs citados neste item. Neles podemos distinguir um certo empenho de conhecer: "O malogro lamentável da noite levou-me a tentar aplicar finalmente a reforma de vida que tenho na cabeça há muito tempo" (BARTHES, 2012a, p. 457); "Excelente método para secar o desejo: contrato a longo termo; isso acaba caindo sozinho" (BARTHES, 2004b, p. 102). As duas entradas de diário são fechadas com uma "moral da história". A escrita volta-se a um exterior, porém a relação não é de colheita-reprodução, mas de intercâmbio: é também um espaço de ação na experiência.

A dinâmica pode ser pensada a partir do termo usado por Barthes para arrematar: "Disso esta primeira nota é o vestígio." (BARTHES, 
2012a, p. 457, grifo nosso). A narração é colocada em primeiro plano pelo dêitico, e sua caracterização como vestígio coloca a escrita do diário como a um tempo diretamente ligada a um acontecimento e dele distinta. Ao mesmo tempo, a perspectiva de que o caminho trilhado será refeito tem suas próprias implicações. As noitadas, espaço do não-trabalho, ou ao menos da não-escrita, são invadidas pela prática do diário (que, pelas indicações figuradas, é redigido na manhã seguinte). Porém, a própria deliberação de que adentrarão a escrita é suficiente para introduzir uma dobra em seu tecido: quem mantém um diário passa a escrever sua vida, a incluir nas experiências a perspectiva da passagem à escrita, operando uma contaminação mútua entre esta e a vida.

Uma mistura semelhante ocorre em A Câmara Clara. Vejamos o início do livro:

Um dia, há muito tempo, dei com uma fotografia do último irmão de Napoleão, Jerônimo (1852). Eu me disse então, com um espanto que jamais pude reduzir: "Vejo os olhos que viram o Imperador." Vez ou outra, eu falava desse espanto, mas como ninguém parecia compartilhá-lo, nem mesmo compreendê-lo (a vida é, assim, feita a golpes de pequenas solidões), eu o esqueci. Meu interesse pela Fotografia adquiriu uma postura mais cultural. Decretei que gostava da Foto contra o cinema, do qual, todavia, eu não chegava a separá-la. Essa questão se fazia insistente. Em relação à Fotografia, eu era tomado de um desejo "ontológico": eu queria saber a qualquer preço o que ela era "em si", por que traço essencial ela se distinguia da comunidade das imagens. (BARTHES, 1984, p. 11-12, grifo do autor)

A dicção de Câmara aproxima-se dos artigos e ensaios no sentido de que Barthes não explicita a máscara enunciativa como fizera nos dois livros anteriores. Destaca Roger:

(...) A Câmara Clara é sem justificação também no sentido mais comum: Barthes não sente qualquer necessidade de se justificar nele, como fazia ainda na abertura de Roland Barthes por Roland Barthes, ou no prefácio de Fragmentos..., por uma captatio retórica em que se obrigava a produzir o esboço de uma teoria do sujeito, ou ainda a exibir um protocolo de enunciação; nesse respeito, é forte o vínculo entre o "livro do Eu" e Fragmentos..., livros do sujeito inocentado por diversos projetos de "simulação": fazer como se eu fosse Roland Barthes, fazer como se eu fosse "um apaixonado que fala e que diz...". (...) 
Nesse sentido, A Câmara clara é também o único livro íntimo de Barthes. Nem prefácio, nem post-scriptum; lá não há nada enquadrando a escrita; o livro não prepara mais o território do escritor, não mais gere sua retirada. Daí, talvez, sua força. ${ }^{11}$ (ROGER, 1986, p. 198, grifos do autor, tradução nossa)

O livro a princípio propõe acompanharmos alguém no périplo de investigação da Fotografia. Não há convite explícito nem paratextual argumentando o interesse da leitura, como ocorre nos Fragmentos de um Discurso Amoroso e em $S / Z$, entre outros. A Câmara Clara abre-se por uma frase de formulação narrativa, quase fabular, a qual radica o projeto numa inquietação que não é dada como demonstrável, diferentemente do método analítico do $S / Z$, nem oferecida para apropriação do leitor, como as categorias prazer/gozo do Prazer do Texto; ela é proposta como uma "pequena solidão", fora de toda possibilidade de partilha. Mesmo em um dispositivo comunicacional como o livro, é reivindicado um caráter absolutamente pessoal para o interesse na fotografia. Inicialmente, é como se fôssemos convidados não a uma aventura de conhecimento ou a uma experiência estética, mas a algo muito mais simples: ouvir uma história.

Tal história tem antecedentes: há recuperação de afirmações anteriores sob o nome de autor Roland Barthes a respeito da fotografia; revisão das posições, revelação de bastidores. É significativa a ausência de tensionamento da continuidade do "eu", empreendido tantas vezes sob a assinatura Roland Barthes. Um dos elementos que suavizam a problematização do "eu" como questão enunciativa em Câmara é o mesmo a possibilitar os métodos investigativos adotados no percurso: a proeminência concedida à relação entre o narrador e a matéria narrada, tanto na narração de Câmara quanto nas fotografias ali trazidas.

Notamos anteriormente que em "Noites de Paris" o protagonismo das narrativas era quase sempre do próprio narrador; algo semelhante se passa no último livro de Barthes:

Mais valia (...) tentar fazer da "antiga soberania do eu" (Nietzsche) um princípio heurístico. Resolvi tomar como ponto de partida de minha busca apenas algumas fotos, aquelas que eu estava certo de que existiam para mim. (...). Aceitei então tomar-me por mediador de toda a Fotografia: eu tentaria formular, a partir de alguns movimentos pessoais, o traço fundamental (...). (BARTHES, 1984, p. 19, grifo do autor)

Ao colocar-se como referencial da investigação, o narrador de $C \hat{a}-$ mara faz-se pilar e constituinte do discurso. Sem recursos de ocultamen- 
to, como abreviar os nomes, nem cautelas de evidenciação da máscara enunciativa (como "tudo isso deve ser considerado como dito por um personagem de romance", no Roland Barthes, ou "é um apaixonado que fala e diz", em Fragmentos), a subjetividade em questão em Câmara é afetiva: espantada diante do irmão de Napoleão, ferida pela morte da mãe. Em termos do fragmento 1 do livro, o que distinguiria a fotografia é que nela coexistem técnica discursiva e o incontornável de uma presença, um corpo, da mesma forma como pode acontecer na enunciação barthesiana às voltas com um "bom eu". Nos romances em que Barthes diz fundar seu desejo de escrita romanesca, tanto quanto no "eu" que traçamos em Câmara, essa presença está relacionada menos a uma verificabilidade referencial do que a uma avassaladora verdade do afeto que acompanha o grama de referente. Como explica Barthes em A preparação do romance:

"Momento de verdade" = (...) Momento de uma história, de uma descrição, de uma enunciação, nó repentino no cursus da leitura, que adquire um caráter excepcional: conjunção de uma emoção que submerge (até as lágrimas, até a agitação) e de uma evidência que imprime em nós a certeza de que aquilo que lemos é a verdade (foi a verdade). (BARTHES, 2005, p. 215-216)

Portanto, Momento de Verdade: a) no plano do sujeito: arrebatamento emotivo, grito visceral (sem expressão histérica): o corpo se junta à metafísica (...)

Momento de verdade $=$ quando a própria Coisa é atingida pelo Afeto; nada de imitação (realismo), mas coalescência afetiva; (...) Momento do Intratável: não se pode interpretar, nem transcender (...). (idem, p. 219-221)

A verdade do afeto e a verdade do "eu" em Câmara se alimentam mutuamente, atualizando um corpo ao texto e um corpo no texto, fornecendo a um pontos de ancoragem e ao outro, de fuga, fazendo vibrar ambos sobre o intervalo entre linguagem e experiência, reestabelecendo um contato complexo, multidirecional.

O narrador de Câmara é consideravelmente conflado no nome de autor Barthes. O êxito na conjunção de texto e afeto é obtido pela substituição de uma dinâmica transmissiva, de passagem afeto-texto-afeto, por uma dinâmica de vestígio trabalhado em monumento. Assim como a nota de "Noites" preserva um resquício da vontade do narrador de mudar de vida, o luto integra Câmara como vestígio: traz a nesga biográfica a um 
plano discursivo (figurativo) e desempenha também uma função textual, como prova dos nove do método:

Leio ao mesmo tempo: isso será e isso foi; observo com horror um futuro anterior cuja aposta é a morte. Ao me dar o passado absoluto da pose (aoristo), a fotografia me diz a morte no futuro. O que me punge é a descoberta dessa equivalência. Diante da foto de minha mãe criança, eu me digo: ela vai morrer: estremeço, tal como o psicótico de Winnicott, por uma catástrofe que já ocorreu. Que o sujeito já esteja morto ou não, qualquer fotografia é essa catástrofe. (BARTHES, 1984, p. 142, grifos do autor)

O vestígio do luto, sua incontornável ligação com o dado biográfico, lhe confere uma sobrevida como existência narrativa. Da mesma forma, Câmara recusa a referencialidade à foto da mãe, que não é reproduzida no livro mas nele existe textualmente: é descrita, escrita.

Cartonada, os cantos machucados, de um sépia empalidecido, mal deixava ver duas crianças de pé, formando grupo, na extremidade de uma pequena ponte de madeira em um Jardim de Inverno com teto de vidro. Minha mãe tinha na ocasião cinco anos (1898), seu irmão tinha sete. Ele apoiava as costas na balaustrada da ponte, sobre a qual estendera o braço; ela, mais distante, menor, mantinha-se de frente; sentia-se que o fotógrafo lhe havia dito: "Um pouco para frente, para que a gente possa te ver"; ela unira as mãos, uma segurando a outra por um dedo, como com freqüência fazem as crianças, num gesto desajeitado. (...)

Observei a menina e enfim reencontrei minha mãe. A claridade de sua face, a pose ingênua de suas mãos, o lugar que docilmente ela havia ocupado, sem se mostrar nem se esconder, sua expressão, enfim (...). (BARTHES, 1984, p. 101-102)

(Não posso mostrar a Foto do Jardim de Inverno. Ela existe apenas para mim. Para vocês, não seria nada além de uma foto indiferente (...) nela, para vocês, não há nenhuma ferida.) (idem, p. 110)

O dado referencial-biográfico faz-se, pela reiteração do narrador, indispensável, porém não esgota o desempenho textual do luto; atua antes como um obtuso grão de areia que impede a dissolução total do corpo no anonimato do texto. Como observa Bellocchio ao relacionar enunciação em Barthes e Benveniste:

Como enunciação, pois, a escritura implica o "lugar e a energia do sujeito" - como também a sua falta - e nela e a partir dela se torna possí- 
vel uma gama de relações que se instauram em relação a esse sujeito na língua. Finalmente, a referência às projeções, (...) e aos sabores acaba por ligar a escritura a uma demanda pessoal, material, em relação com o mundo e com a língua. (BELLOCCHIO, 2014, p. 180)

A pesquisadora reflete sobre Aula (BARTHES, 2007), em que Barthes propõe a literatura como uma atividade de deslocamentos nos discursos de saber e na própria língua. Vemos algo dessa dinâmica da escritura em Câmara, que trabalha discursivamente a presença do sujeito no texto. Temos assim um "eu” complexo: não está restrito a uma existência textual, nem precede dela. É a dupla recusa das convenções, ou o desvencilhar-se da dicotomia, que permite superar a necessidade da declaração "eu valho mais do que aquilo que escrevo": ao incluir judiciosamente na escrita a biografia, "sem se mostrar nem se esconder", de modo que a referência não se esgote na referencialidade, mas adquira espessura textual. Fratura de dois sistemas fechados, seguros: um em que o texto está superposto à experiência, outro em que o texto, e por conseguinte o autor, está dela exilado. 


\section{TWO JOURNALS, AN ESSAY AND A NOVEL: "INCIDENTS" AND "SOIRÉES DE PARIS" IN THE NARRATIVE BY ROLAND BARTHES}

\section{ABSTRACT}

In his final years, Barthes spoke publicly about the project of writing a novel with the working title Vita Nova, which imbued the course "The Preparation of the Novel". During that course he also wrote his last book, Camera Lucida, all while working on the journals "Incidents" and "Soirées de Paris", possibly intending to integrate them into Vita Nova (PINO, 2010). These journals connect biography to author image, self-image, affection and writing, all of which are implicated in the intended novel. Their formal aspects, especially those pertaining to negotiating the terrain between narrating and providing an account of events, can be of interest in reading Camera Lucida and its proposed relationship between the narrator and the photographs that move his text. This paper outlines the presence of "Incidents" and "Soirées de Paris" in some Camera Lucida's narrative aspects that may point at writing choices extendable to the novel desired by Barthes.

KEYWORDS: Roland Barthes, journal, Incidents, Camera Lucida, The Preparation of the Novel

NOTAS

${ }^{1}$ BIRNBAUM, J. La publication d'inédits de Barthes embrase le cercle de ses
disciples. Le Monde, Paris, 21 de janeiro de 2009. Disponível em: $<$ http://www.
lemonde.fr/culture/article/2009/01/21/la-publication-d-inedits-de-barthes-embra-
se-le-cercle-de-ses-disciples_1144698_3246.html>. Acesso em: 30 out. 2014.
${ }^{2}$ MARTY, E. Il n'y a pas d'affaire Roland Barthes. Le Nouvel Observateur. 23 de
janeiro de 2009. Disponível em: $<\underline{\text { http://bibliobs.nouvelobs.com/essais/20090123. }}$ 
BIB2874/il-n-039-y-a-pas-d-039-affaire-roland-barthes.html>. Acesso em 30 out. 2014. Também BROCAS, A. Pour la publication des inédits de Barthes. Le Magazine Littéraire. 21 de janeiro de 2009. Disponível em: <http://www.magazine-litteraire.com/actualite/publication-inedits-barthes-21-01-2009-33580>. Acesso em 30 out. 2014.

${ }^{3}$ A preocupação era que o texto fosse utilizado para julgamentos morais, um pouco como ocorre em Roland Barthes: le metier d'écrire pela pena de Éric Marty (2006, p. 100, tradução nossa): “A segunda [coisa de que eu não gostava em Barthes] dizia respeito ao mundo árabe. Quando ele me fez ler Incidentes, série de fragmentos ligados à sua estadia no Marrocos, (...) em meu íntimo qualquer coisa não aderia ao texto. (...) eu não gostava da espécie de má-fé que agitava o desejo de Barthes nesse texto. Havia ao mesmo tempo o desejo do sexo dos jovens árabes e um olhar condescendente e cheio de desprezo por seu "falocentrismo". É desprezar aquilo que se deseja. O desejo de ter acesso ao pênis sempre disponível, sempre exibido dos adolescentes árabes e, ao mesmo tempo, o fato que essa disponibilidade apareça como algo que os inferiorizava eram uma expressão típica da mentira, da fragilidade. Barthes não publicou [o texto]. Sinal de que ele sentia que alguma coisa ali de fato não colava.”

${ }^{4}$ Cf. "Da obra ao texto" e "A morte do autor", ambos em O rumor da língua. Trad. Mário Laranjeira. 3. ed. São Paulo: WMF Martins Fontes, 2012.

5 "[le sujet] doit plutôt se penser du côté d'un sujet humoral, variable et, comme chez Nietzsche, perpétuellement tendu vers son devenir. La pratique du fragment est ici d'ordre éthique: l'affirmation d'une vérité (du sujet) reste provisoire (...). S'il faut un JE, c'est parce qu'on ne saurait se passer d'un corps (...), parce que seul un corps peut être ému, touché. Mais ce JE n'épaissit pas (...) - il sert plutôt (comme le JE du commentaire face à un texte) de médiateur structural des effets de langue ou d'émotion sur lui."

${ }^{6}$ sugerimos a leitura de SILVA (2015), PINO (2013) - em especial o item 1.2.4 "O romance como antidiário" - e de FONTANARI (no prelo), particularmente o item "O fragmento e a fotografia: o trabalho poético do haikai"; uma aproximação preliminar do tema pode ser consultada também em OLIVEIRA (2010).

${ }^{7}$ Cf. Marty (2006b); também OLIVEIRA, P. P. L. A boca, a fala e a língua em Fragmentos de um Discurso Amoroso. In: Simpósio Roland Barthes, um caso de amor: 40 anos de Fragmentos de um Discurso Amoroso. 2017, Fortaleza.

${ }^{8}$ A primeira redação do texto data do verão de 1977. Pequenos trechos foram publicados no artigo "Deliberação" e em Roland Barthes, Album: inédits, correspondances et varia, livro organizado postumamente por Éric Marty (2015).

${ }^{9}$ Modulation toute singulière de cette question caractéristique d'une certaine litté- 
rature moderne (Flaubert, Proust, Kafka), qu'il n'a cessé, anxieusement, d'interroger: «J'écris pour savoir si je puis, si je dois écrire.»

${ }^{10}$ The manuscript of 'Deliberation' also has some intriguing marginal annotations for the 'Futile Evening': 'Beginning of an old-style Novel'; 'I sense here the inflexion that would transform the autobiographical I into the I of a character in a novel.' In short, it seems likely that the Journal d'Urt, with the Paris Evenings already visible in its last entries, though written in the difficult circumstances of his mother's rapidly declining health, was already conceived as a testing out and reflection on the worth of the diary-form as literature.

11 “(...) sans justification, la Chambre claire l'est aussi au sens le plus ordinaire: Barthes n'éprouve nul besoin de s'y justifier, comme il faisait encore en tête de Roland Barthes par Roland Barthes, ou dans la préface de Fragments..., par une captatio rhétorique qui s'obligeait à produire pour titres l'esquisse d'une théorie du sujet, ou encore à exhiber un protocole d'énonciation; à cet égard, le lien est fort entre le «livre du Moi» et Fragments..., livres du sujet innocenté par divers projets de «simulation»: faire comme si j'étais Roland Barthes, faire comme si j'étais «un amoureux qui parle et qui dit...». (...) En ce sens, la Chambre claire est aussi le seul livre intime de Barthes. Ni préface ni post-scriptum; on n'y trouvera plus rien de ce qui encadrait l'écriture; le livre n'aménage plus le territoire de l'écrivain, il ne lui ménage plus de retraite. D'où, peut-être, sa force."

\section{REFERÊNCIAS}

BARTHES, Roland. A Câmara Clara: nota sobre a fotografia. Tradução Júlio Castañon Guimarães. 2. ed. Rio de Janeiro: Nova Fronteira, 1984.

BARTHES, Roland. A preparação do romance I: da vida à obra. Tradução Leyla Perrone-Moisés. São Paulo: Martins Fontes, 2005. (Col. Roland Barthes).

BARTHES, Roland. Aula. Tradução Leyla Perrone-Moisés. São Paulo: Cultrix, 2007.

BARTHES, Roland. Deliberação. In: BARTHES, R. O rumor da língua. Tradução Mario Laranjeira. São Paulo: WMF Martins Fontes, 2012a. p. 445-462.

BARTHES, Roland. Diário de luto. 26 de outubro 1977 - 17 de setembro de 1979. Tradução Leyla Perrone-Moisés. São Paulo: Martins Fontes, 2011.

BARTHES, Roland. Durante muito tempo, fui dormir cedo. In: BARTHES, R. O 
rumor da língua. Tradução Mário Laranjeira. 3. ed. São Paulo: Martins Fontes, 2012b. .

BARTHES, Roland. Incidentes. In: BARTHES, R. Incidentes. Tradução Mario Laranjeira. São Paulo: Martins Fontes, 2004a. p. 11-50. (Col. Roland Barthes)

BARTHES, Roland. La préparation du roman I et II. Cours et séminaires au Collège de France (1978-1979 et 1979-1980). Texte établi, annoté et présenté par Nathalie Léger. Paris: Seuil, 2003.

BARTHES, Roland. Noites de Paris. In: BARTHES, R. Incidentes. Tradução Mário Laranjeira. São Paulo: Martins Fontes, 2004b. p. 59-110.

BARTHES, Roland. CEuvres Complètes. In: BARTHES, R. Paris: Seul, 2002. v. V, p. 1008-1014.

BARTHES, Roland. Roland Barthes por Roland Barthes. Tradução Leyla Perrone-Moisés. São Paulo: Cultrix, 1977.

BELLOCCHIO, Carolina Molinar. Da Morte ou o Entrar na Escritura: Enunciação em Barthes e Benveniste. Criação \& Crítica, n. 12, p. 172-181, 2014. Disponível em: <http://revistas.usp.br/criacaoecritica>. Acesso em: 30 mar. 2015.

CALVET, Louis-Jean. Roland Barthes: uma biografia. Tradução Maria Ângela Vilela Da Costa. São Paulo: Siciliano, 1993.

CAMARGO, Maria Lucia de Barros. Atrás dos olhos pardos: uma leitura da poesia de Ana Cristina César. Chapecó: Argos, 2003.

GENETTE, Gérard. Le journal, l'antijournal. Poétique, v. 47, p. 315-322, 1981.

KNIGHT, Diana. arthes deliberates: Pascal, Ignatius and the question of the diary. Textual Practice, v. 30, n. 2, p. 221-239, 2016. Disponível em: <https://www. tandfonline.com/doi/full/10.1080/0950236X.2016.1129726>. Acesso em: 5 jul. 2018.

MAINGUENEAU, Dominique. Le discours littéraire. Paris: Armand Colin, 2013.

MARTY, Éric. Roland Barthes: le métier d'écrire. Paris: Seuil, 2006a.

MARTY, Éric. Sur les «Fragments d'un discours amoureux». Réflexions sur l'image. In: Roland Barthes, le métier d'écrire. Paris: Seuil, 2006b. p. 191-336.

OLIVEIRA, Priscila Pesce Lopes De. "Incidents" na produção barthesiana. 2010. Monografia (Iniciação Científica em Letras) - Faculdade de Filosofia, Letras e Ciências Humanas, Universidade de São Paulo, São Paulo, 2010.

PINO, Claudia Amigo. Em busca de uma vida nova: no caminho do romance de Roland Barthes. Manuscrítica - revista de crítica genética, n. 16, p. 41-55, 2010. Disponível em: <http://revistas.fflch.usp.br/manuscritica/issue/view/93/ 
show/Toc>. Acesso em: 1 out. 2014.

PINO, Claudia Amigo. Em busca de uma vida nova: o projeto de romance de Roland Barthes. 2013. 214 f. Universidade de São Paulo, São Paulo, 2013.

RABATÉ, Dominique. Roman, discours, note: le singulier pluriel chez Roland Barthes. In: MACÉ, M.; GEFEN, A. (Orgs.). Barthes, au lieu du roman. Paris: Desjonquères/Nota Bene, 2002. p. 195-217.

ROGER, Philippe. Roland Barthes, roman. Paris: Grasset \& Fasquelle, 1986.

SILVA, Márcio Renato Pinheiro. Roland Barthes, da História ao Haicai. Criação \& Crítica, n. 14, p. 60-75, 2015. Disponível em: $<$ http://revistas.usp.br/criacaoecritica>. Acesso em: 30 jun. 2015.

WAHL, François. Nota do editor francês. In: BARTHES, R. Incidentes. Tradução Mário Laranjeira. São Paulo: Martins Fontes, 2004. p. VII-XI.

Recebido: 23/01/2018

Aceito: $07 / 06 / 2018$ 